\title{
Interval TpTe Diagnostic Value in Diastolic Dysfunction of Patients with Hypertension
}

\author{
Rano Irmawan*, Braghmandaru Adhi Bhaskara, Hasanah Mumpuni, Nahar Taufiq \\ Department of Cardiology and Vascular Medicine \\ Faculty of Medicine Universitas Gadjah Mada - Dr. Sardjito Hospital, Yogyakarta, Indonesia
}

Corresponding author :

Rano Irmawan, MD, - email: ranoirmawan@gmail.com

Department Cardiology and Vascular Medicine, Faculty of Medicine Universitas Gadjah Mada - Dr. Sardjito Hospital, Yogyakarta, Indonesia, Jalan Farmako Sekip Utara, Yogyakarta 55281

Manuscript submitted: June 21, 2017; Revised and accepted: January 24, 2018

\begin{abstract}
Introduction: Diastolic dysfunction has been shown to be associated with an increase in mortality rates in both normal and decreased systolic function. In patients with hypertension, there is elongation of transmural repolarization dispersion in left ventricular, which will cause heart diastolic relaxation disorders. The elongation of the transmural repolarization dispersion is indicated by the increase of the TpTe interval. We conducted this study to find out whether the TpTe interval had a good diagnostic value in detecting diastolic dysfunction in patients with hypertension.
\end{abstract}

Methods: This is an analytic observational research using cross sectional design on hypertensive patients in whom echocardiography was performed. The study conducted in February 2017 until March 2017 in Dr. Sarjito general hospital Yogyakarta. Electrocardiography examination was taken after the patient was performed echocardiography. The TpTe interval was calculated using the 'tail' method at lead V5. Diastolic dysfunction was established using echocardiography with the ASE / EAE 2016 algorithm.

Results: Of the 112 patients met the criteria of the study subjects. The cut-off value for TpTe was 103.97 m.s., based R.O.C curve analysis. TpTe interval $\geq 103.97$ m.s. had a moderate diagnostic value for detecting diastolic dysfunction with $73 \%$ accuracy, $83 \%$ sensitivity, $64 \%$ specificity, $22 \%$ positive predictive value, and $97 \%$ negative predictive value. There were $66(58.9 \%)$ subjects with TpTe interval $<103.97$ m.s. and 46 subjects $(41.1 \%)$ with TpTe interval $\geq 103.97$ m.s. There were 12 subjects $(10.7 \%)$ with diastolic dysfunction. Bivariate and multivariate analyzes showed no demographic and clinical factors that independently affected the TpTe interval.

Conclusion: The TpTe interval $\geq 103.97$ m.s. had a moderate diagnostic value for detecting diastolic dysfunction in patients with hypertension.

Keywords: TpTe interval, diastolic dysfunction, hypertension

\section{INTISARI}

Latar Belakang: Disfungsi diastolik telah diketahui berhubungan dengan peningkatan angka mortalitas baik pada fungsi sistolik yang masih normal maupun yang sudah mengalami penurunan. Pasien dengan hipertensi akan mengalami pemanjangan dispersi repolarisasi transmural pada ventrikel kiri, yang akan menyebabkan gangguan diastolik relaksasi jantung. Pemanjangan dispersi repolarisasi transmural ditunjukkan dengan pemanjangan interval TpTe. Kami melakukan penelitian ini untuk mengetahui apakah interval TpTe mempunyai nilai diagnostik yang baik dalam mendeteksi disfungsi diastolik pada pasien hipertensi.

Metode Penelitian: Penelitian observasional analitik dengan menggunakan disain penelitian potong lintang terhadap pasien hipertensi yang dilakukan ekokardiografi pada Februari 2017 sampai dengan Maret 2017 di Rumah Sakit Dr. Sardjito, Yogyakarta, Indonesia. Pemeriksaan 
elektrokardiografi diambil setelah pasien dilakukan ekokardiografi. Parameter interval TpTe dihitung menggunakan metode 'ekor' pada sandapan V5. Disfungsi diastolik ditegakkan menggunakan ekokardiografi dengan algoritma ASE/EAE 2016.

Hasil: Terdapat 112 pasien yang memenuhi kriteria subyek penelitian. Nilai titik potong untuk TpTe adalah 103,97 milidetik, berdasarkan kurva R.O.C. Interval TpTe $\geq 103,97$ milidetik memiliki nilai diagnostik sedang untuk mendeteksi disfungsi diastolik dengan nilai akurasi sebesar $73 \%$, sensitivitas sebesar $83 \%$, spesifisitas $64 \%$, nilai duga positif $22 \%$, dan nilai duga negatif $97 \%$. Terdapat 66 (58,9\%) subyek dengan interval TpTe <103.97 milidetik dan 46 subyek $(41,1 \%)$ dengan interval TpTe $\geq 103,97$ milidetik. Terdapat 12 subyek (10,7\%) dengan disfungsi diastolik. Analisis bivariat dan multivariat menunjukkan tidak ada faktor demografis dan klinis yang berpengaruh secara independen terhadap interval TpTe.

Simpulan: TpTe interval $\geq 103.97$ milidetik mempunyai nilai diagnostik sedang untuk mendeteksi disfungsi diastolik pada pasien dengan hipertensi.

\section{INTRODUCTION}

Diastolic dysfunction has been shown to correlate with an increase in mortality rates in both normal and decreased systolic function. ${ }^{1}$ The current prevalence of diastolic dysfunction in studies conducted in the European population was $22.97 \%^{2}$ and the prevalence of diastolic dysfunction in hypertensive patients was $43 \%{ }^{3}$

In patients with hypertension changes in the $\mathrm{Na}^{+}, \mathrm{K}^{+}$and $\mathrm{Ca}^{2+}$ ion channels in the left ventricle will result in increase of action potential duration (APD) as well as elongation transmural repolarization dispersion (TRD) left ventricle, which will lead to left ventricle diastolic relaxation disorders..${ }^{4,5}$ Currently there are several methods of electrocardiographic calculation that serves to know the TRD, such as T peak - T end interval (TpTe) and QT interval. The TpTe interval in electrocardiography depicts the left ventricular transmural repolarization dispersion that is associated with left ventricular relaxation mechanical dispersion in echocardiography. ${ }^{6}$

Electrocardiography (ECG) which shows repolarization has been known to be associated with mechanical relaxation of left ventricle. Research conducted by Alessandrini et al revealed that changes in ECG repolarization were associated with changes in echocardiography examination i.e, increased T-wave amplitude representing increase in ventricular filling rate peak, while QT interval increase was associated with increased IVRT. ${ }^{7}$ The elongation of the TRD is represented by the increase of the TpTe interval, i.e. the time interval measured from the peak of the T wave to the end of the T wave. ${ }^{8}$

Diagnosing diastolic dysfunction is important because electrocardiographic devices are an enormous tool in Indonesian primary health cares, but little research on ECG ability in diagnosing diastolic dysfunction. We are interested in conducting this study because we want to know the diagnostic value of TpTe interval with diastolic dysfunction in hypertension.

\section{RESEARCH METHOD}

This research is analytic observational research using cross sectional design. The subjects of the study were patients with hypertension who performed echocardiography examination. Target population is hypertensive patients performed echocardiography examination in the Dr. Sardjito General Hospital Yogyakarta since January 2017 and meet the criteria of the study selected by consecutive sampling.

The inclusion criteria of study subjects were hypertension performed echocardiography with normal systolic ejection fraction, normokinetic, age 18-75 years old and willing to follow the research. The exclusion criteria for this study were diastolic function indeterminate, congenital heart disease, primary heart valve disease, 
ventricular conduction disorder, patients with permanent pacemaker, patients in the treatment of arsenic trioxide, bretylium, chloroquine, cisapride, disopyramide, erithromycin, pimozide, quinidine, tetracycline, and amiodarone and ECG recordings with flat $T$ wave, inversion, artifact, or multiphasic.

The method of ECG measurements by way of recording 12 leads was performed in patients with supine position, at a speed of 50 $\mathrm{mm} /$ second with a sensitivity of $20 \mathrm{~mm} / \mathrm{mV}$ using General Electric MAC i. We scanned the
ECG by Canon Canoscan Lide 110 300dpi and than calculate TpTe interval using Image $\mathrm{Q}($. We measured interval TpTe in lead V5 with 'tail' method which is measured from the peak or nadir of the $T$ wave to the point where the wave reached the isoelectric line as explained in previous study. ${ }^{9}$ The 12 lead positions were laid out according to the ECG checking standards ${ }^{10}$ and performed on the same day as echocardiography.

Echocardiographic examination was performed by experienced technicians under the

Table1. The basic characteristics of hypertensive subjects performed echocardiography ( $n=112$ subjects)

\begin{tabular}{|c|c|}
\hline Variables & Frequency \\
\hline \multicolumn{2}{|l|}{ Sex } \\
\hline Male, n (\%) & $42(37.5 \%)$ \\
\hline Female, n (\%) & $70(62.5 \%)$ \\
\hline Age $\left(\right.$ years) ${ }^{*}$ & $58.06 \pm 11.07$ \\
\hline Pulse rate $(\mathrm{bpm})^{\star \star}$ & $77.50(47-100)$ \\
\hline \multicolumn{2}{|l|}{ Blood Pressure $(\mathrm{mmHg})^{\star \star}$} \\
\hline Systolic** & $140(100-200)$ \\
\hline Diastolic ${ }^{* *}$ & $80(50-110)$ \\
\hline Diabetes melitus, n (\%) & $11(9.8 \%)$ \\
\hline Smoking habit, n (\%) & $16(14.3 \%)$ \\
\hline Ischemic heart disease, n (\%) & $4(3.6 \%)$ \\
\hline ACE inhibitor, n (\%) & $10(8.9 \%)$ \\
\hline Angiotensin receptor blocker, n (\%) & $28(25 \%)$ \\
\hline Calcium channel blocker, n (\%) & $27(24.1 \%)$ \\
\hline Beta blocker, n (\%) & $18(16.1 \%)$ \\
\hline Thiazide type diuretic, $\mathrm{n}(\%)$ & $0(0 \%)$ \\
\hline Digoxin, n (\%) & $0(0 \%)$ \\
\hline Aldosteron blocker, n (\%) & $0(0 \%)$ \\
\hline \multicolumn{2}{|l|}{ Echocardiography } \\
\hline $\operatorname{LVIDd}(\mathrm{mm})^{*}$ & $44.9 \pm 4.89$ \\
\hline IVSDd $(\mathrm{mm})^{* *}$ & $10(6-17)$ \\
\hline LVPWDd $(m m)^{* *}$ & $9(6-16)$ \\
\hline LAVI $\left(\mathrm{ml} / \mathrm{m}^{2}\right)^{* *}$ & $21(10-61)$ \\
\hline $\mathrm{e}^{\prime}$ medial $(\mathrm{cm} / \mathrm{s})^{* *}$ & $8(3-17)$ \\
\hline $\mathrm{e}^{\prime}$ lateral $(\mathrm{cm} / \mathrm{s})^{* *}$ & $10(4-29)$ \\
\hline Rasio E/e'** & $7.37(0-22)$ \\
\hline Tricuspid regurgitation velocity $(\mathrm{m} / \mathrm{s})^{* *}$ & $0(0-144)$ \\
\hline $\mathrm{dT}(\mathrm{ms})^{* *}$ & $198(0-466)$ \\
\hline LV mass $(g)^{* *}$ & $143.5(59.91-357.47)$ \\
\hline
\end{tabular}


supervision of a cardiologist. The interpretation of echocardiography results was performed by a cardiologist echocardiography consultant who had performed intraobserver kappa tests prior to the study. The measurement of echocardiography and diastolic dysfunction criteria used in this study were in accordance with those recommended by American Society of Echocardiography 2016. ${ }^{11}$ The ethical committee of Faculty of Medicine Universitas Gadjah Mada had approved the study.

\section{RESULT}

\section{Characteristics of subjects}

The study took place from January 2017 to March 2017 at Dr. Sardjito General Hospital Yogyakarta. During this period as many as 270 subjects had a history of hypertension. A total of 107 subjects were excluded because of a decreased ejection fraction, 43 subjects had primary heart valve abnormalities, 2 subjects had congenital cardiac abnormalities, 3 subjects had an early ECG image with inverse T wave, and 3 subjects had a biphasic T wave.

The test of kappa interobserver performed obtained value of 0.81 with $p<0.001$, meaning there is a very strong match between the two observers. Assessment of diastolic function was performed by one echocardiogram consultant cardiologist who had done intraobserver kappa test with a value of 0.82 with $p<0.05$.

The study included 112 patients who were included as research subjects and met inclusion and exclusion criteria.

Analysis of diagnostic values of TpTe interval on diastolic function

To determine the diagnostic value of TpTe interval on diastolic function in hypertensive patients, the receiver operating characteristics (ROC) curve analysis was performed to obtain

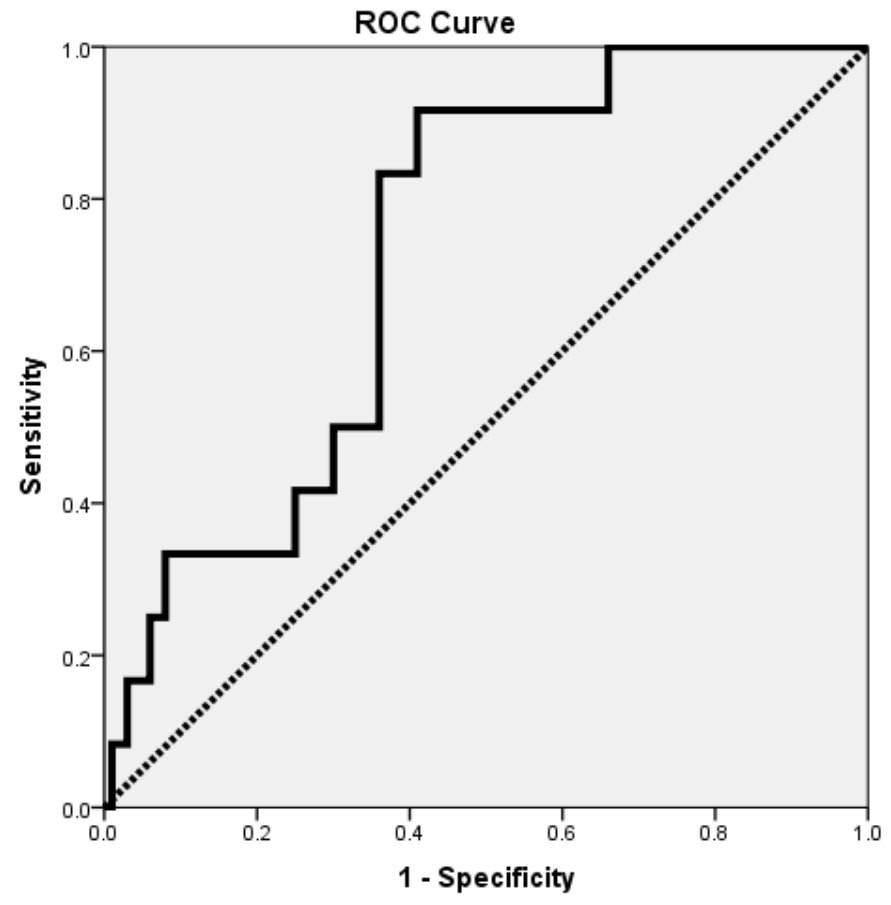

Figure 1. Receiver Operating Characteristic (ROC) curve of interval Tp-Te diagnostic value in diastolic dysfunction of hypertension patients. Area Under Curve (AUC) was 73\% (95\% Cl $60.8 \%-85.2 \%)$, p value $=0.009$. 


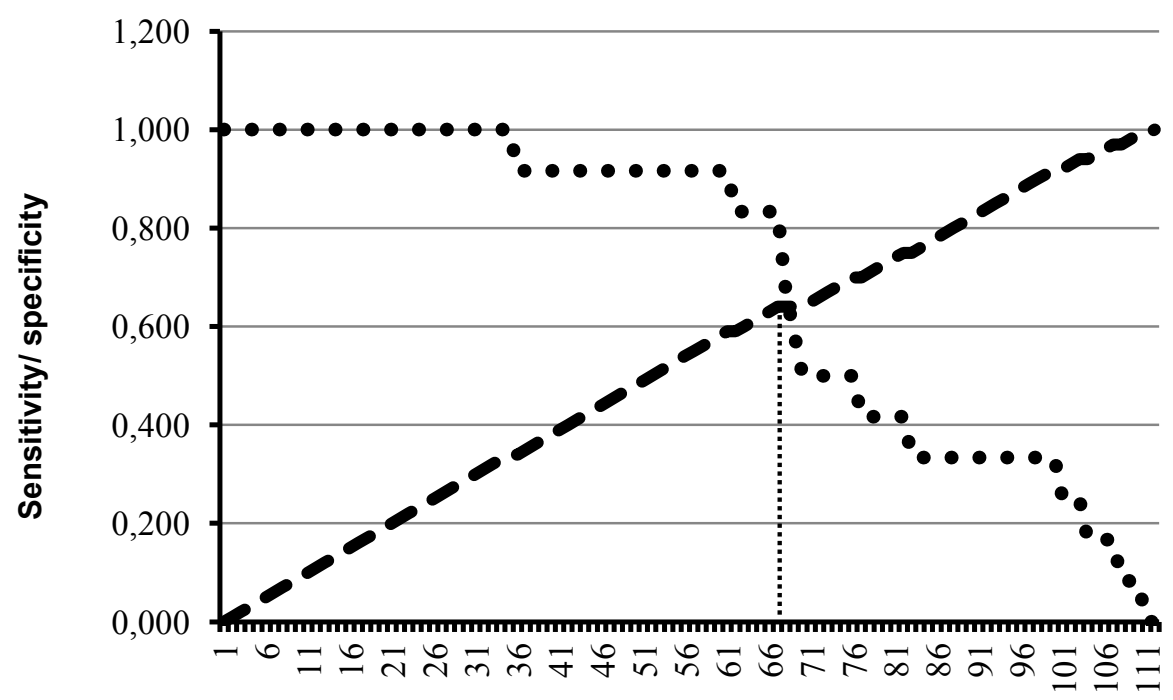

Serial number of subjects based on TpTe interval

Figure 2. Graph of sensitivity (round line) and specificity (dash line) of TpTe interval against diastolic dysfunction in hypertensive subjects performed echocardiography. The vertical dotted lines represent the most optimal intersection of sensitivity and specificity.

Table 2. Analysis of diagnostic value of TpTe interval against diastolic dysfunction in hypertensive subjects performed echocardiography

\begin{tabular}{|c|c|c|c|c|}
\hline & & \multicolumn{2}{|c|}{ TpTe Interval } & Total \\
\hline & & $\geq 103.97$ m.s & $<103.97$ m.s & \\
\hline \multirow{3}{*}{$\begin{array}{c}\text { Echocardio } \\
\text { graphy }\end{array}$} & Diastolic Dysfunction & 10 & 2 & 12 \\
\hline & Normal & 36 & 64 & 100 \\
\hline & Total & 46 & 66 & 112 \\
\hline
\end{tabular}

Sensitivity: $10 /(10+2)=10 / 12=83.33 \%$

Specificity: $64 /(36+64)=64 / 100=64 \%$

Positive predictive value: $10 /(10+36)=10 / 46=21.74 \%$

Negative predictive value: $64 /(2+64)=64 / 66=96.96 \%$

the value of area under the curve (AUC) and to determine the intersection point of TpTe interval with the optimum sensitivity and specificity. The sensitivity and specificity tests were then performed using $2 \times 2$ tabulation.

The ROC curve analysis obtained AUC values of $73 \%(95 \% \mathrm{Cl}: 60.8 \%-85.2 \%), p=0.009$ and the cut-off point of TpTe interval obtained in 103.97 m.s., which had optimal sensitivity and specificity. The sensitivity was $83.33 \%$ and specificity was $64 \%$ for that cut-off point. We then analyzed with the TpTe interval cut-off point of 103.97 m.s. using a $2 \times 2$ as the following tabulation (table 2). Based on the analysis, the result of sensitivity was $83.33 \%$, specificity was $64 \%$, positive predictive value was $21.74 \%$ and negative predictive value was $96.96 \%$.

Analysis of the factors that influence the TpTe interval.

Several confounding variables that have been known from previous studies may have an effect on the TpTe interval. Factors that may affect were diabetes mellitus, ischemic heart disease, drug use that affects calcium channels in the myocardium, ACE inhibitor, beta 
blockers, calcium channel blockers, digoxin and aldosterone blockers, and anti-hypertensive drugs that do not affect the canal calcium, angiotensin-receptor blockers and thiazidetype diuretics. Bivariate test was conducted to determine the correlation of these factors to TpTe interval. Factors that have a value $<0.25$ from bivariate test will be performed multivariate analysis to see whether these factors independently affect the interval TpTe considered significant if $p<0.05$.

We did bivariate analysis for gender parameters, age, heart rate, blood pressure, diabetes mellitus, smoking, ischemic heart disease, ACE inhibitor, angiotensin receptor blocker, calcium channel blocker, and beta blocker. Based on the bivariate analysis in the table 3 , we found $p$ value $<0.25$ in age parameters, diastolic blood pressure, diabetes mellitus, ischemic heart disease and on angiotensin receptor blockers. Furthermore analyzed by multivariate analysis, we present in Table 4 below.
Multivariate analysis was not obtained $p$ $<0.05$ for all variables tested. Therefore, it can be concluded that there was no independent variables that influence TpTe interval in this research.

\section{DISCUSSION}

Our study involved 112 subjects with 12 subjects $(10.7 \%)$ were people with diastolic dysfunction. The research subjects were classified into 2 groups based on the cut-off point TpTe interval. The cut-off point was obtained through statistical analysis using ROC curve to obtain the specificity and sensitivity of TpTe most optimal interval in diagnosing diastolic dysfunction, cut-off point value that is obtained is 103.97 m.s. The analysis of ROC curve in our study obtained $73 \%$ AUC (95\% Cl: $60.8 \%$ $-85.2 \%)$ with $p=0,009$. It showed $83.33 \%$ sensitivity, $64 \%$ specificity, positive prediction value $21.74 \%$ and negative predictive value $96.96 \%$.

Table 3. Bivariate analysis of factors that influence the TpTe interval in the subjects of hypertensive patients performed echocardiography

\begin{tabular}{|c|c|c|c|c|c|}
\hline \multirow{2}{*}{ Variable } & \multicolumn{2}{|c|}{ TpTe Interval } & \multirow{2}{*}{ OR } & \multirow{2}{*}{ CI 95\% } & \multirow{2}{*}{$P$ value } \\
\hline & $<103.97 \mathrm{~ms}(\mathrm{n}=66)$ & $\geq 103.97 \mathrm{~ms}(\mathrm{n}=46)$ & & & \\
\hline \multicolumn{6}{|l|}{ Sex } \\
\hline Male, n (\%) & $22(33.3 \%)$ & $20(43.5 \%)$ & \multirow{2}{*}{0.65} & \multirow{2}{*}{$0.29-1.41$} & \multirow{2}{*}{0.28} \\
\hline Female, $\mathrm{n}(\%)$ & $44(66.7 \%)$ & $26(56.5 \%)$ & & & \\
\hline Age (years old)* & $56.35 \pm 12.17$ & $60.53 \pm 8.8$ & 1.76 & $0.82-3.77$ & 0.07 \\
\hline Pulse rate ${ }^{* *}$ & $80(47-100)$ & $75(54-100)$ & 1.81 & $0.85-3.89$ & 0.42 \\
\hline \multicolumn{6}{|l|}{ Blood Pressure } \\
\hline Systolic** & $140(110-190)$ & $140(100-200)$ & 0.96 & $0.45-2.05$ & 0.99 \\
\hline Diastolic** & $80(60-110)$ & $80(50-110)$ & 0.66 & $0.29-1.44$ & 0.18 \\
\hline Diabetes melitus, $\mathrm{n}(\%)$ & $4(6.1 \%)$ & $7(15.2 \%)$ & 0.36 & $0.99-1.31$ & 0.10 \\
\hline Smoking habit, n (\%) & $8(12.1 \%)$ & $8(17.4 \%)$ & 0.66 & $0.23-1.89$ & 0.43 \\
\hline Ischemic heart disease, n (\%) & $1(1.5 \%)$ & $3(6.5 \%)$ & 0.22 & $0.22-2.19$ & 0.19 \\
\hline ACE inhibitor, $n(\%)$ & $7(10.6 \%)$ & $3(6.5 \%)$ & 1.7 & $0.42-6.96$ & 0.35 \\
\hline AR blocker, $\mathrm{n}(\%)$ & $12(18.2 \%)$ & $16(34.8 \%)$ & 0.42 & $0.17-0.99$ & 0.05 \\
\hline Calcium channel blocker, $\mathrm{n}(\%)$ & $15(22.7 \%)$ & $12(26.1 \%)$ & 0.83 & $0.35-1.99$ & 0.68 \\
\hline Beta blocker, n(\%) & $9(13.6 \%)$ & $9(19.6 \%)$ & 0.65 & $0.24-1.79$ & 0.4 \\
\hline
\end{tabular}


Table 4. Multivariate analysis of factors influencing TpTe interval in subjects with hypertension performed echocardiography

\begin{tabular}{|c|c|c|c|c|c|}
\hline \multirow{2}{*}{ Variabel } & \multicolumn{2}{|c|}{ Interval TpTe } & \multirow{2}{*}{ OR } & \multirow{2}{*}{ CI $95 \%$} & \multirow{2}{*}{$\begin{array}{c}P \\
\text { value }\end{array}$} \\
\hline & $<103.97 \mathrm{~ms}(\mathrm{n}=66)$ & $\geq 103.97 \mathrm{~ms}(\mathrm{n}=46)$ & & & \\
\hline Age $\geq 58$ years old $*$ & $31(47 \%)$ & $28(60.9 \%)$ & 0.64 & $0.29-1.43$ & 0.28 \\
\hline Diastolic blood pressure $\geq 80 \mathrm{mmHg}^{* *}$ & $28(42.4 \%)$ & $15(32.6 \%)$ & 1.19 & $0.51-2.75$ & 0.69 \\
\hline Diabetes melitus, n (\%) & $4(6.1 \%)$ & $7(15.2 \%)$ & 2.20 & $0.58-8.34$ & 0.25 \\
\hline Ischemic heart disease, $\mathrm{n}(\%)$ & $1(1.5 \%)$ & $3(6.5 \%)$ & 3.12 & $0.28-34.2$ & 0.35 \\
\hline AR blocker, $n(\%)$ & $12(18.2 \%)$ & $16(34.8 \%)$ & 1.85 & $0.74-4.68$ & 0.19 \\
\hline
\end{tabular}

$\mathrm{OR}$ is odds ratio, $\mathrm{Cl}$ is confidence interval , $\mathrm{AR}$ is angiotensin receptor

* cut-off point 58 years old based on mean value of age

${ }^{* *}$ cut-off point $80 \mathrm{mmHg}$ based on median value of diastolic blood pressure

Echocardiography with the ASE/EAE 2009 algorithm has a $98 \%$ sensitivity and $91 \%$ specificity in diagnosing diastolic dysfunction compared to gold standard, ${ }^{12}$ while the ASE/EAE 2016 algorithm has a better ability to determine diastolic dysfunction. ${ }^{13}$ This study showed that the TpTe interval examination $\geq 103.97$ m.s. had a good sensitivity and negative predictive value, in addition ECG examination was more widely available than echocardiography examination, indicating that this examination could be used as a screening tool for the diagnosis of diastolic dysfunction in hypertensive patients prior to echocardiography examination.

We performed bivariate and multivariate analyzes on the basic characteristics of research subjects to investigate confounding factors against TpTe intervals in this study. Multivariate analysis resulted that the variables studied had no independent effect on the TpTe interval because $p>0.05$.

Our study found that there were no significant differences in the sex variables between the two groups. This is in accordance with a study conducted by Sauer et al who found no significant difference in gender variables in his study that examined the relationship of TpTe interval and diastolic dysfunction. ${ }^{6}$

Our study found that there were no significant differences in age variables between the two groups. Research conducted by Zhao et al. (2010) who examined the association of left ventricular hypertrophy with TpTe interval also found no significant age differences in normotensive subjects group, hypertension without left ventricular hypertrophy and hypertension with left ventricular hypertrophy. ${ }^{14}$ Research conducted Sauer et al.(2012) found a group of subjects with $\geq 75$ m.s. TpTe interval had an older age than in subjects with TpTe interval $<75$ m.s. ${ }^{6}$ This difference is due to differences in study subjects in our study with research conducted by Sauer et al., previous research had the subjects performed a treadmill test and involved subjects with regional wall motion abnormality and decreased left ventricular ejection fraction. ${ }^{6}$

Our study found that blood pressure and pulse rate at the time of ECG recording did not influence independently of the TpTe interval, in accord to a previous studyl. ${ }^{6}$ Our study found that there was no significant difference in the age, sex and velocity variables in which this was consistent with the previous statements. The TpTe interval was used as an indicator of repolarization heterogeneity because it has a consistent, independent predictive value of clinical outcome age, sex, and heart rate..$^{15,16}$

The study found that the majority of diabetes mellitus had TpTe interval $\geq 103.97$ m.s., although the difference between the two groups was not significant. This is consistent with the Sauer et al. study in which the majority of diabetes mellitus had a TpTe interval of $\geq 75$ m.s. and this difference was not significant 
when compared to the subject group with TpTe interval $<75$ m.s. ${ }^{6}$ Clemente et al.(2012) studied 110 normal subjects and 110 subjects with diabetes mellitus and stated that there was a significant TpTe interval difference between the two groups. ${ }^{17}$ The study explained that in patients with diabetes mellitus there will be disturbance of autonomous regulation and electrical inhomogeneity in the heart so that will cause increase of TpTe interval. ${ }^{17}$ Our study showed that there was no significant difference in the variables of diabetes mellitus, this is because the number of subjects with diabetes mellitus is small and the proportion does not differ significantly between the two groups.

In this study, 4 subjects were found to have ischemic heart disease, the majority of subjects with ischemic heart disease had TpTe interval $\geq 103.97$ m.s. Xiao-ming et al. (2010) who suggested that subjects with severe coronary artery stenosis had longer TpTe intervals than moderate and mild coronary artery stenosis, this was due to changes in the potassium canal in myocardial ischemia due to coronary heart disease..$^{18}$ The variable of ischemic heart disease in this study did not affect the TpTe interval because the number of subjects suffering from ischemic heart disease was few in number and the proportion did not differ significantly between the two groups.

Our study showed that there was no significant difference in smoking habits between the two groups. There has been no research examining the links cigarette smoking with $\mathrm{TpTe}$ interval, but the study of Zhang et al. (2011) found that smoking does not affect the QT interval. QT interval is one of the ECG indicators that describes the heterogeneity of left ventricular repolarization in addition to TpTe interval. ${ }^{19}$

Drugs ACE inhibitors, angiotensin receptor blockers, beta blockers, calcium channel blockers, thiazide-type diuretics, aldosterone blockers and digoxin in this study had no effect independently of TpTe interval. In a study by
Roche et al, it was found that arsenic trioxide, bretylium, chloroquine, cisapride, disopyramide, erithromycin, pimozide, quinidine, tetracycline, enalapril, and propanolol would elongate TpTe interval while verapamil and amiodarone would shorten TpTe intervals. In this study, the types of drugs consumed by the subjects were captopril, ramipril, lisinopril, valsartan, candesartan, telmisartan, bisoprolol, and amlodipine. ${ }^{20}$ Drugs consumed by this study subjects were not included in the study by Roche et al.(2005) and had similar proportions in both groups. The results of this study were consistent with the Sauer et al. study that did not find significant differences between the groups with TpTe interval $<75$ m.s. and $\geq 75$ m.s. in variable use of ACE inhibitors / angiotensin receptor blockers, beta blockers and diuretics. ${ }^{6}$ The drugs in this study did not affect the TpTe interval because the number of subjects using the drugs was few in number and the proportions did not differ significantly between the two groups.

\section{LIMITATION}

The limitation of this study is the small proportion of subjects with diastolic dysfunction, so it may not be able to accurately describe the condition of diastolic dysfunction in the population.

\section{REFERENCES}

1. Halley C.M., Houghtaling P.L., Khalil MK, Thomas JD, Jaber WA. 2011. Mortality rate in patients with diastolic dysfunction and normal systolic function. Arch Intern Med, 171:1082-1087.

2. Kloch-badelek M., Kuznetsova T., Sakiewicz W., Tikhonoff V., Ryabikov A., González A., et al. 2012. Prevalence of left ventricular diastolic dysfunction in European populations based on cross-validated diagnostic thresholds. Cardiovasc Ultrasound, 10:1-9. 
3. Mohamed A.L., Yong J., Masiyati J., Lim L., Tee S.C. 2004. The prevalence of diastolic dysfunction in patients with hypertension referred for echocardiographic. Malaysian $\mathrm{J}$ Med Sci, 11:66-74.

4. Mozos I., Serban C. 2011. The relation between QT interval and T - wave variables in hypertensive patients. J Pharm Bioallied Sci, 3:339-345.

5. Barison A., Vergaro G., Pastormerlo L.E., Ghiadoni L., Emdin M., Passino C. 2011. Markers of arrhythmogenic risk in hypertensive subjects. Curr Pharm Des, 17:3062-3073.

6. Sauer A., Wilcox J.E., Andrei A., Passman R., Goldberger J.J., Shah S.J. 2012. Diastolic electromechanical coupling association of the ECG T-peak to T-end interval with echocardiographic markers of diastolic dysfunction. Circ Arrhythm Electrophysiol, 5:537-543.

7. Alessandrini R.S., Mcpherson D.D., Kadish A.H., Goldberger J., Mcpherson D.D., Kadish H., et al. 1997. Cardiac memory : a mechanical and electrical phenomenon. Am Physiol Soc, H1952-H1959.

8. Gupta P., Patel C., Patel H., Narayanaswamy S., Malhotra B., Green J.T., et al. 2008. Tp-e/ QT ratio as an index of arrhythmogenesis. J Electrocardiol, 41:567-574.

9. Erikssen G., Liestøl K., Gullestad L., Haugaa K.H., Bendz B., Amlie J.P. 2012. The terminal part of the QT interval ( T peak to T end ): a predictor of mortality after acute myocardial. Ann Noninvasive Electrocardiol, 17:85-94.

10. Akhtar M. 1990. Examination of the heart. Part 5: The Electrocardiogram. Am Hear Assoc, 1990;3-13.

11. Nagueh S.F., Smiseth O.A., Appleton C.P., Byrd B.F., Dokainish H., Edvardsen T., et al. 2016. Recommendations for the evaluation of left ventricular diastolic function by echocardiography : An Update from the
American Society of Echocardiography and the European Association of Cardiovascular Imaging. J Am Soc Echocardiogr, 29:277-314.

12. Nagueh S.F., Bhatt R., Vivo R.P., Krim S.R., Sarvari S.I., Russell K., et al. 2011. Echocardiographic evaluation of hemodynamics in patients with decompensated systolic heart failure. Circ Cardiovasc Imaging, 4:220-227.

13. Sato K., Grant A.D.M., Negishi K., Cremer P.C., Kumar A., Collier P., et al. 2017. Reliability of updated left ventricular diastolic function recommendations in predicting elevated left ventricular filling pressure and prognosis. Am Heart J, 189:28-39.

14. Zhao Z., Yuan Z., Ji Y., Wu Y., Qi Y. 2010. Left ventricular hypertrophy amplifies the QT, and Tp-e intervals and the Tp-e/QT ratio of left chest ECG. J Biomed Res, 24:69-72.

15. Smetana P., Schmidt A., Zabel M., Hnatkova K., Franz M., Huber K., etal. 2011. Assessment of repolarization heterogeneity for prediction of mortality in cardiovascular disease : peak to the end of the T wave interval and nondipolar repolarization components. J Electrocardiol, 44:301-308.

16. Haarmark C., Graff C., Andersen M.P., Hardahl T., Struijk J.J., Toft E., et al. 2010. Reference values of electrocardiogram repolarization variables in a healthy population. J Electrocardiol, 43:31-39.

17. Clemente D., Pereira T., Ribeiro S. 2012. Ventricular repolarization in diabetic patients : characterization and clinical implications. Arq Bras Cardiol. 99:1015-22.

18. Xiao-ming L., Xi-li Y., He-ling L., Yu-qiong L. 2010. Relationship between TpeakTend interval and coronary artery stenosis and effects of percutaneous transluminal coronary angioplasty on Tpeak-Tend. J South Med Univ, 30:1877-1879.

19. Zhang Y., Post W.S., Dalal D., Blascocolmenares E., Tomaselli G.F., Guallar E. 
2011. Coffee, alcohol, smoking, physical activity and QT interval duration : results from the Third National Health and Nutrition Examination Survey. PLoS One, 6:1-7.
20. Roche B.M., Kijtawornrat A., Hamlin R.L., Hamlin D.M. 2005. Relationship between prolongation of QTC and prolongation of the peak of $T(T p)$ to the end of $T(T e)$. J Pharmacol Toxicol Methods, 52:178-181. 